\title{
Připravenost učitelů k ochraně bezpečí žáků v případech mimořádných událostí ohrožujících život a zdraví
}

\author{
Competence of teachers to protect pupils in emergency threatening their life and health
}

\author{
Eva Marádová, Jaroslava Hanušová
}

\begin{abstract}
Abstrakt: V př́spěvku jsou předloženy dílčí výsledky výzkumné studie zaměřené na získávání podkladů pro implementaci problematiky ochrany člověka za mimořádných událostí a zásad poskytování první pomoci do učitelského vzdělávání. Potřeba inovace vzdělávání v této oblasti vyplývá ze skutečnosti, že v současném světě je ohrožení v důsledku mimořádných událostí stále častější. Proto je toto téma nově zahrnuto $\mathrm{v}$ rámcových vzdělávacích programech pro základní, gymnaziální a střední odborné vzdělávání. Cúlem výzkumného projektu realizovaného na Univerzitě Karlově v Praze - Pedagogické fakultě bylo zmapovat znalosti studentů učitelství a vychovatelství o problematice ochrany za mimořádných událostí a postihnout úroveň jejich dovedností souvisejících s poskytováním první pomoci. Propojení kvantitativních a kvalitativních metod výzkumu umožnilo získat vhled do současné edukační reality ve výchově k ochraně za mimořádných událostí a zároveň odhalit aktuální vzdělávací potřeby budoucích učitelů v dané oblasti. Výsledky šetření budou využity při vytváření nové koncepce začleňování sledované problematiky do studijních programů na fakultách připravujících učitele.
\end{abstract}

Klíčová slova: ochrana člověka za mimořádných událostí, výchova ke zdraví, vzdělávání učitelů

\begin{abstract}
Abstrakt: The contribution includes presentation of research outcomes dealing with implementation of the field human protection in emergency and first aid principles into teacher training. Nowadays the need for innovation in human protection grows. That's why this thematic unit is newly integrated in the Framework Educational Programs of primary and secondary schools. The aim of the research conducted at Charles University - Pedagogical Faculty was to monitor level of future teachers' knowledge of protection in emergency, to find out their educational needs in the field of providing first aid. Combining quantitative and qualitative research methods provided an insight into current educational reality of protection in emergency and helped to identify current educational needs of future teachers in the field. The outcomes will be used for the new conception of integrating the thematic unit into educational programs at teacher-training faculties.
\end{abstract}

Keywords: human protection in emergency, education towards health, teacher training 


\section{1 Úvod}

Ohrožení obyvatelstva $\mathrm{v}$ důsledku tzv. mimořádných událostí ${ }^{*}$ nelze $\mathrm{v}$ žádné době podceňovat. $\mathrm{V}$ posledních letech se na základě varujících zkušeností ze světa (teroristické útoky, ničivá zemětřesení) i z České republiky (opakující se povodně) dostává opět do popředí veřejného i odborného zájmu potřeba vytvořit komplexní systém ochrany obyvatelstva. Současná Koncepce ochrany obyvatelstva do roku 2013 s výhledem do roku 2020, schválená usnesením vlády č. 165 ze dne 25. 2. 2008, zdůrazňuje význam vzdělávání a zvyšování spoluodpovědnosti občanů za svoji ochranu. Vychází z předpokladu, že dobře informovaný člověk dokáže reálněji posuzovat nebezpečné situace, předcházet vzniku mimořádné události a $\mathrm{v}$ př́ípadě potřeby pomoci nejen sobě, ale i ostatním.

Téma ochrany člověka za mimořádných událostí je proto nově zahrnuto $\mathrm{v}$ rámcových vzdělávacích programech pro základní, gymnaziální a střední odborné vzdělávání. Implementace problematiky ochrany člověka za mimořádných událostí do školních vzdělávacích programů a realizace vytvořených programů v praxi škol vyžaduje odborně připravené a metodicky erudované pedagogy.

Cíle vymezené usnesením vlády a návazné požadavky transformované školy jsou především výzvou pro fakulty připravující pedagogické pracovníky. V této souvislosti je proto od r. 2006 rozvíjena úzká spolupráce Generálního ředitelství Hasičského záchranného sboru a oddělení výchovy ke zdraví na PedF UK v Praze na dlouhodobém projektu tvorby studijních základů pro budoucí pedagogy. Cílem projektu je zajistit, aby budoucí učitelé a vychovatelé byli v rámci vysokoškolského studia připravováni na plnění úkolů spojených s ochranou zdraví a bezpečí dětí, žáků a studentů v př́ípadě událostí ohrožujících život a zdraví.

\section{Teoretická východiska projektu}

\subsection{Vzdělávání v oblasti ochrany za mimorádných událostí v historickém kontextu}

V úvodní etapě projektu (2006-2007) byla provedena komplexní analýza legislativních a procesních podmínek pro implementaci ochrany za mimořádných událostí do pregraduální př́pravy pedagogů. Vycházela $\mathrm{z}$ historického kontextu vývoje platné legislativy, kterou byly určovány cíle a obsah výuky na základních a středních školách a následně i vysokoškolská př́prava učitelů $\mathrm{v}$ minulých čtyřiceti letech. Výstupem této etapy byla studie poskytující obraz o vývoji celospolečenského př́stupu k otázkám ochrany za mimořádných událostí doložený podrobným přehledem dokumentů (zákony, vyhlášky, metodické pokyny), na jejichž základě vzdělávání probíhalo (resp. mělo probíhat). Vyhodnocení poznatků o vývoji cílů, obsahu i forem vzdělávání v této oblasti umožnilo využít určité vybrané zkušenosti jako jedno z východisek při koncipování nového výukového modelu.

V této souvislosti připomeňme nejdůležitější fakta: V letech 1973-1991 byla Zákonem č. 73/1973 Sb., o branné výchově, ustanovena povinná výuka branné výchovy na ZŠ a SS̆. V období let 1991 - 1999 (po zrušení branné výchovy) neprobíhala na školách žádná výuka, ani nebyla realizována př́prava učitelů. Od 1. 9. 1999 dle Pokynu MŠMT čj. 34776/98-22 bylo všem ZŠ a SŠ uloženo začlenit tuto problematiku do výuky. Dle Usnesení vlády ČR č.

\footnotetext{
„Mimořádná událost - škodlivé působení sil a jevů vyvolaných činností člověka, prírodními vlivy, a také havárie, které ohrožuji život, zdraví, majetek nebo životní prostředí a vyžaduji provedení záchranných a likvidačních praci“" (Zákon č. 239/2000 Sb., o integrovaném záchranném systému a změně některých zákonů).
} 
11, ze dne 8. 1. 2003 byly pokyny MŠMT ČR aktualizovány (Pokyn M ̌̌MT čj. 12 050/03-22). V r. 2003 byla ochrana člověka za mimořádných událostí vřazena do vzdělávacích dokumentů (školy měly povinnost tuto tematiku zařadit $\mathrm{v}$ rozsahu nejméně 6 vyučovacích hodin ročně $\mathrm{v}$ každém ročníku). Příprava učitelů však probíhala pouze v rámci kurzů celoživotního vzdělávání.

\subsection{Ochrana za mimořádných událostí v transformované škole}

Pro posuzování současných podmínek pro vzdělávání obyvatelstva o možných mimořádných událostech a správných postupech $\mathrm{v}$ př́ípadě ohrožení byly $\mathrm{v}$ rámci projektu dále shromážděny aktuální dokumenty k problematice ochrany za mimořádných událostí: legislativní rámec, zapojení a kompetence jednotlivých resortů se zaměřením na oblast školství. Byl vypracován přehled odborných publikací, které jsou v současné době k dispozici.

V návaznosti na probíhající transformační proces ve školství je nyní téma ochrany člověka za mimořádných událostí zahrnuto $\mathrm{v}$ rámcových vzdělávacích programech pro základní, gymnaziální a střední odborné vzdělávání. Jsou zde vymezeny konkrétní očekávané výstupy. Realizace očekávaných výstupů RVP předpokládá, že všechny školy v ČR budou do svých školních vzdělávacích programů implementovat tematický okruh Ochrana člověka za mimořádných událostí, a to systematicky, v návaznosti na věková specifika a potřeby žáků. Doporučuje se, aby při realizaci výuky na 2. stupni ZŠ byl jako základní prostor pro spirálovité rozvíjení problematiky využit předmět Výchova ke zdraví.

\section{Výzkumné šetření}

Zjišt’ování reálných možností začlenění tematiky „Ochrana člověka za mimořádných událostí“ do studijních programů pregraduálního vzdělávání pedagogů bylo obsahem navazující II. etapy projektu. V letech 2008-2010 bylo na UK v Praze - Pedagogické fakultě realizováno výzkumné šetření, jehož výstupy se staly základem pro návrh obsahu studijního modulu, který by bylo možno (po ověření na PedF UK) nabídnut k využití ostatním vysokým školám připravujícím učitele.

\subsection{Cíle a metodika orientační sondy mezi studenty učitelství}

Nezbytným východiskem pro koncipování efektivního studijního programu př́pravy pedagogů je objektivní posouzení současné edukační reality voblasti ochrany za mimořádných událostí. Ve snaze vytvořit dostatečný základ jak v rovině teoretické, tak i v návaznosti na potřeby praxe, byla připravena a realizována orientační výzkumná sonda zaměřená na studenty pregraduálního učitelského studia.

Cílem bylo sledovat úroveň informovanosti studentů učitelství v problematice ochrany za mimořádných událostí, zjistit jejich vzdělávací potřeby v dané oblasti a posoudit jejich připravenost působit na žáky v souladu s platným kurikulem.

Východiskem pro formulaci hypotézy (znalosti studentů dosahují minimálně úrovně $60 \%$ ) byl především předpoklad, že mimořádné události jsou v současnosti realitou a tedy dovednosti potřebné pro ochranu zdraví a života velmi potřebné. Navíc dle pokynu MŠMT (2003) byla problematika ochrany člověka za mimořádných událostí vřazena do vzdělávacích programů na Z $\breve{S}$ a SS̆.

Metodou výzkumu bylo anonymní dotazníkové šetření. Speciálně pro tento účel koncipovaný dotazník byl distribuován studentům různých studijních oborů na UK v Praze - Pedagogické fakultě. Bylo získáno celkem 210 kompletně vyplněných dotazníků. Ve sledované skupině 
převažovali respondenti, kteří navštěvovali střední školu v období, kdy bylo všem školám uloženo začlenit do výuky tematiku ochrany člověka za mimořádných událostí.

\subsection{Vybrané výsledky výzkumu znalostí}

K závažným zjištěním patř́ informace o zkušenostech respondentů se školní výukou ochrany za mimořádných událostí. Přestože školská legislativa od r. 2003 jednoznačně ukládá povinnost věnovat se problematice ochrany za mimořádných událostí na všech typech základních a středních škol, 63 \% oslovených respondentů uvedlo, že nebylo během svého studia na střední či vyšší odborné škole seznámeno s touto problematikou (Obrázek 1).

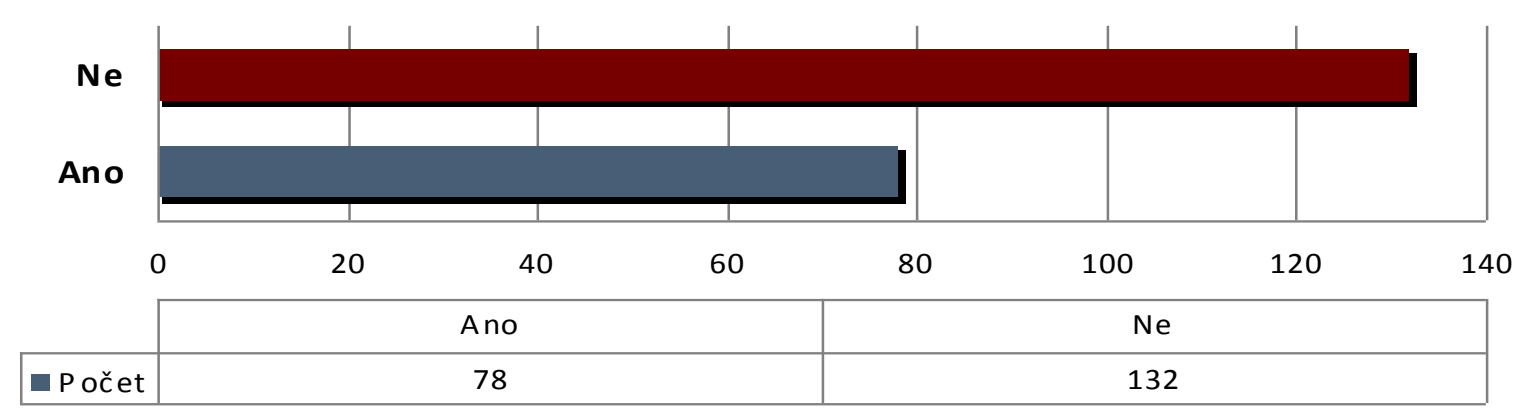

Obrázek 1. Byl/a jste během svého studia na stř̌ední či vyšší odborné škole seznámen/a s ochranou za mimořádných událostí?

Výzkumná sonda odhalila značné nedostatky ve znalostech absolventů středních škol. Hypotéza se nepotvrdila, tj. nelze počítat s $60 \%$ informovaností budoucích učitelů. Alarmující je řada odpovědí. Např́klad pouze v pěti př́padech $(2 \%)$ oslovení respondenti správně pojmenovali kolísavý tón sirény po dobu 140 sekund (všeobecnou výstrahu). Všechny tři složky Integrovaného záchranného systému správně uvedlo jen 94 (45\%) respondentů. O určitém nezájmu může svědčit fakt, že pouze $74(35 \%)$ studentů vědělo, kde se nalézá shromaždiště PedF UK v Praze. Evakuační plány jsou přitom k dispozici na veřejně př́stupných místech fakulty. Zvláště znepokojující byly odpovědi týkající se poskytování laické první pomoci. Např́klad postup při kardiopulmonální resuscitaci znalo pouze 53 ( $25 \%)$ účastníků šetření.

Obavu z poskytování laické první pomoci uvedlo 147 (70 \%) respondentů. V otevřené otázce studenti popisovali okolnosti strachu z poskytování první pomoci. 45 respondentů uvedlo, že jejich strach je spojen s neznalostí správného postupu, 35 dotazovaných se obává, aby neudělali chybu, která by vedla kublížení postiženému. Z vlastního selhání (paniky, nervozity, bezmoci, šoku, reakce na lidskou bolest, z pohledu na krev, strachu sahat na cizí osoby) má hrůzu 18 studentů. Dále byly vysloveny obavy: pomoc nebude dostatečně rychlá a efektivní, možnost nákazy, realita odlišná od nácviku, neodhadnutí situace, panika ze smrti postiženého, možná žaloba a velká odpovědnost, nezvládnutí pomoci po fyzické stránce. Z výpovědí studentů je patrné, že si uvědomují své nedostatečné znalosti z dané oblasti a zejména nepřipravenost poskytnout první pomoc. Právě tuto realitu je třeba zohlednit při př́ípravě vzdělávání budoucích učitelů.

Výše popsaná metodika byla použita i při následném sběru dat na středních a základních školách. Jsou k dispozici vyhodnocené výpovědi žáků Z $\breve{S}$ a $S \breve{S}$, které také prrispěly $\mathrm{k}$ dotvoření obrazu o současné edukační realitě a o vzdělávacích potřebách budoucích učitelů $\mathrm{v}$ dané oblasti. 


\section{Projektování a ověřování nově koncipovaných předmětů}

Na základě komparace výsledků výzkumného šetření byly vymezeny základní požadované kompetence učitelů a vychovatelů $\mathrm{v}$ předmětné oblasti a navržena odpovídající koncepce vzdělávání. S podporou Fondu rozvoje vysokých škol* byl v průběhu roku 2011 připraven a realizován projekt zaměřený na tvorbu a ověřování nového pojetí předmětu Ochrana za mimořádných událostí a první pomoc ve škole.

Projekt zahrnuje inovaci obsahu výuky (po stránce odborné i didaktické) a jeho ověření metodou pedagogického experimentu (podpořené odpovídajícím organizačním zajištěním a pomůckovým vybavením). Předpokládá převážně seminární formu výuky $\mathrm{s}$ využitím studijních textů a praktické lekce nácviku poskytování první pomoci. Vzhledem $\mathrm{k}$ interdisciplinárnímu charakteru obsahu a $\mathrm{k}$ rozsahu dané problematiky spočívá inovace v souběžném využívání přímé výuky a e-learningové formy podpory. Pro experimentální výuku předmětu, která proběhne v zimním semestru 2011/12, byl připraven k ověření také soubor výzkumných nástrojů: dotazníky vstupního testování znalostí a postojů odhalující možnost práce s prekoncepty, záznamové archy pro pozorování a reflexi jednotlivých aktivit, scénář pro pořizování videozáznamů z výuky (nácvik dovedností poskytování první pomoci), podklady (základní otázky) pro ohniskové skupiny (focus groups), záznamové listy pro autoevaluaci.

\section{Závěry}

Výsledky popsaného projektu budou publikovány souhrnně po vyhodnocení pedagogického experimentu. Na podkladě výstupů získaných výzkumným šetřením bude korigován navržený obsah předmětu, upraveny a doplněny vytvořené studijní opory. Kompletní dokumentace předmětu bude nabídnuta pro využití ostatním fakultám připravujícím učitele. Zároveň se však předpokládá, že vytvořený (experimentálně ověřený) metodologický postup smíšeného designu (zahrnující několik vzájemně propojených metod a technik sběru a analýzy dat) bude uplatnitelný pro ověřování dalších shodně obsahově zaměřených předmětů.

\section{Literatura}

Marádová. E., \& Hanušová, J. (2008). Zpráva o realizaci projektu: Ochrana za mimořádných událostí v učitelském vzdělávání. Praha: MV - GŘ HZS ČR.

Marádová. E., \& Hanušová, J. (2009). Readiness of the Future Teachers to Prevention and Protection in emergency. In School and Health 21 - Topical Issues in Health Education (pp. 27-239). Brno: MU, 2009.

Ochrana člověka za mimořádných událostí. (2003). Metodický pokyn MŠMT čj. 13 586/03-22 ze dne 4. března 2003.

\section{Kontakt}

PaedDr. Eva Marádová, CSc.

PhDr. Jaroslava Hanušová, Ph.D.

Univerzita Karlova v Praze

Pedagogická fakulta

M.D.Rettigové 4, 11639 Praha 1

e-mail: eva.maradova@pedf.cuni.cz

jaroslava.hanusova@pedf.cuni.cz

\footnotetext{
* Projekt FRVŠ č. 468 /2011, Ochrana za mimořádných událostí a první pomoc ve škole - inovace předmětů na Pedagogické fakultě UK.
} 


\section{Bibliografické údaje}

Marádová, E., \& Hanušová, J. (2011). Připravenost učitelů k ochraně bezpečí žáků v př́ípadech mimořádných událostí ohrožujících život a zdraví. In T. Janík, P. Knecht, \& S. Šebestová (Eds.), Smišený design v pedagogickém výzkumu: Sborník př́spěvků z 19. výročni konference České asociace pedagogického výzkumu (s. 286-291). Brno: Masarykova univerzita.

Dostupné z: http://www.ped.muni.cz/capv2011/sbornikprispevku/maradovahanusova.pdf doi: 10.5817/PdF.P210-CAPV-2012-37 